\title{
Article \\ A Priority in Land Supply for Sustainable Transportation of Chinese Cities: An Empirical Study from Perception, Discrimination, Linkage to Decision
}

\author{
Ke Wang ${ }^{1}$, Jianjun Zhang ${ }^{1,2, * \mathbb{D}}$, Di Zhang ${ }^{3}$ and Xia $\mathrm{Wu}^{1}$ \\ 1 School of Land Science and Technology, China University of Geosciences, 29, Xueyuan Road, Haidian District, \\ Beijing 100083, China; wangke11260@163.com (K.W.); alisonwuxia@126.com (X.W.) \\ 2 Key Laboratory of Land Consolidation and Rehabilitation, Ministry of Natural Resources, \\ Beijing 100083, China \\ 3 Information Center, Ministry of Natural Resources of the People's Republic of China, Beijing 100036, China; \\ dzhang@126.com \\ * Correspondence: zhangjianjun_bj@126.com or zhangjianjun@cugb.edu.cn
}

check for

updates

Citation: Wang, K.; Zhang, J.; Zhang, D.; Wu, X. A Priority in Land Supply for Sustainable Transportation of Chinese Cities: An Empirical Study from Perception, Discrimination,

Linkage to Decision. Land 2022, 11 , 78. https://doi.org/10.3390/land 11010078

Academic Editor: Thomas W. Sanchez

Received: 4 December 2021

Accepted: 2 January 2022

Published: 5 January 2022

Publisher's Note: MDPI stays neutral with regard to jurisdictional claims in published maps and institutional affiliations.

Copyright: (C) 2022 by the authors. Licensee MDPI, Basel, Switzerland. This article is an open access article distributed under the terms and conditions of the Creative Commons Attribution (CC BY) license (https:// creativecommons.org/licenses/by/ $4.0 /)$.

\begin{abstract}
With the rapid development of China's economy, alleviating the shortage of land resources has become a significant challenge. Transportation infrastructure is a channel connecting cities, which carries the flow of population and material circulation. The efficient allocation of land used for transportation is closely related to production and life. By investigating the main factors affecting the priority of the supply of land used for transportation, this paper evaluates the transportation condition of all cities in China from five aspects: dominance, dependence, coordination, accessibility, and land demand for transportation. Furthermore, this paper constructs a multi-objective decision support system for land supply, which aims to find out which cities are in urgent need of the supply of land for transportation and what types of transportation infrastructure need to be focused on. The results of this paper show that most of the cities with high land supply priority are non-provincial capital cities and are important growth poles of regional economic development. The construction of a comprehensive transportation system is the short-term goal of these cities. Most cities with low land supply priority are sparsely populated, in good ecological condition, and far away from the core areas of economic development. The preferred transportation mode of these cities is generally land transportation. The main contribution of this paper is to provide a comprehensive decision support system for the land management department to determine land supply priorities and achieve the sustainable use of land.
\end{abstract}

Keywords: land supply; sustainable transportation; priority; decision; Chinese cities

\section{Introduction}

Land is an essential carrier for human production and living activities [1-3]. With the advancement of remote sensing technology, land use/cover classification has been extensively studied $[4,5]$, and land used for transportation has become one of the critical land-use types. The change in the development stage of transportation is essentially a response to the shortage of land resources [6]. To alleviate the scarcity of transportation infrastructure, many countries, especially developed or populous countries, have carried out related actions, such as the TRANSPLUS project [7], Sustainable Urban Mobility Plan (SUMP) [8], "Beyond Traffic" plan [9], Smart Mobility 2030 [10], and the "National Comprehensive Three-dimensional Transportation Network" plan.

Since the beginning of the 21st century, China has vigorously promoted the construction of transportation infrastructure, and roads and railways are dominant in transportation infrastructure [11,12]. However, China is still facing tremendous pressure on transportation demand. During the 13th five-year plan period, from 2016 to 2020, some cities (especially 
emerging cities) have already met the practical constraints of land shortage [13]. In addition, according to official statistics from Eurostat and the National Bureau of Statistics of China, the EU's road construction land occupies $1.3 \%$ of the EU's total land. Still, China's land area devoted to transportation accounts for less than $1 \%$ of the total land area (as of the end of 2016), and China's population is nearly three times that of the EU's population, which indicates that there is still a large gap in terms of transportation infrastructure between China and developed regions. Optimizing the allocation of land used for transportation to realize intensive land use is a significant issue facing China's transportation infrastructure construction in the future. From the perspective of land resource management, there are three main research topics related to transportation: (1) research on essential factors that influence the demand for transportation infrastructure, (2) the relationship between transportation and land use, and (3) the evaluation, planning, optimal allocation, and demand forecasting of land used for transportation.

The fundamental cause for the shortage of transportation is the rapid development of the world economy [14,15]. The interaction between transportation and the economy has always been hotly discussed [16,17]. It has been widely recognized that transportation infrastructure plays an important role in national economic development, and there is a positive relationship between transportation development and economic growth [18]. In addition, most studies have also confirmed that population [19], income [20], infrastructure investment [21], industrial development [22,23], employment [24], urbanization [25,26], land use management [27] and car ownership [28] have an important impact on the transportation system.

With the rapid development of the economy, the demand for industrial expansion for transportation services is increasing [29], and the contradiction between transportation construction and land use is intensifying [30]. Previous studies generally separated transportation from the land use system and focused on the interaction between transportation and land use [31,32]. The interaction between these two systems is a dynamic process [33]. The change of transportation system has a direct and indirect effect on the land use system, and there is a time lag in the effect [34]. The direct impact is that the construction of transportation infrastructure will inevitably occupy land resources [35], and the indirect impact is that the improvement of the transportation system will lead to the simultaneous establishment of multiple supporting facilities [36]. Moreover, the effect of transportation on the land-use system has two sides. The positive impact is mainly the promotion of industrial development, and the negative impact is the hindrance to the protection of ecological areas [37]. Based on understanding the interaction between transportation and land use, the current research focuses on optimizing urban land-use patterns from the perspective of sustainable transportation development [38], and conducts transportation and land use policy analysis [39].

There have been some studies which have integrated transportation and land use and researched these from the perspectives of efficiency evaluation [40,41], optimal allocation [42,43], and demand forecasting of land used for transportation [44]. It is a common goal to realize sustainable development through land-use allocation optimization $[45,46]$. The allocation of land used for transportation is divided into three levels: the macro-, mesoand micro-levels [47]. The macro-level land allocation means that the land administration department adjusts the supply and demand of land used for transportation through land use plans to balance the macroeconomic, social, and environmental benefits of land use [48]. The meso-level land allocation considers the form, type, time, and space of land allocation to adapt to different regions and subjects [49]. The micro-level land allocation is about how to reasonably save and use land resources during project construction [50]. In addition, demand forecasting of land used for transportation is an essential part of land use planning and transportation strategic planning [51,52]. The forecasting method of land demand is mainly quantitative analysis, including the regression model [53], trend extrapolation method [54], Markov chain model [55], grey model [56], system dynamics [57], and neural network [58]. 
China is still in a prosperous period of transportation construction, which places great demands on land used for transportation. Under the socialist market economy system, the Chinese government still plays an essential role in allocating transportation resources. Current researches on transportation and land use are primarily concentrated in cities or urban agglomerations, and there is no research to put forward the supply of land used for transportation from the perspective of all prefecture-level cities in China. To improve the land supply efficiency of China's transportation sector, this paper takes all prefecture-level cities in China as the research object and proposes a land supply suggestion based on sustainable urban development, which provides an essential reference for the formulation and implementation of China's transportation strategic planning. The purpose of this paper is to: (1) construct a transportation land supply decision support system serving the national strategic planning and development, (2) comprehensively evaluate the transportation conditions of Chinese cities from the dominance, dependence, coordination, accessibility, and land demand forecasting, and (3) propose the decision reference of supply of land used for transportation with a clear order and type.

The remainder of this paper is structured as follows. Section 2 introduces the data source, research framework, and methodology. Section 3 details the condition of transportation land use from five aspects and presents the results of transportation land supply decisions in Chinese cities. Sections 4 and 5 discusses and concludes this study.

\section{Materials and Methods}

\subsection{Data Source}

The data used in this paper include: spatial data, statistical data and other data. Spatial data is mainly used for accessibility analysis and spatial visualization analysis. Statistical data is used to evaluate and forecast land demand for transportation construction, and this is the basic data for constructing a transportation land supply decision support system. Other data come from Chinese officials, which are mainly used to determine the city's preferred transportation mode and validate the reliability of the research results (Table 1).

Table 1. Descriptions of data types used.

\begin{tabular}{|c|c|c|c|}
\hline Type & Data & Format & Description \\
\hline \multirow{3}{*}{ Spatial data } & $\begin{array}{l}\text { Map of administrative divisions in } \\
\text { China }\end{array}$ & Vector & $\begin{array}{l}\text { Ministry of Natural Resources of the People's } \\
\text { Republic of China (http:/ / bzdt.ch.mnr.gov.cn/ } \\
\text { (accessed on } 5 \text { June 2021)) }\end{array}$ \\
\hline & $\begin{array}{c}\text { China integrated transportation } \\
\text { network map }\end{array}$ & Vector & http:/ / www.gov.cn / (accessed on 5 June 2021) \\
\hline & $\begin{array}{l}\text { National key ecological functional } \\
\text { zones map }\end{array}$ & Vector & $\begin{array}{l}\text { National Development and Reform Commission } \\
\text { (http:/ / www.gov.cn / xinwen/2017-02/09 } \\
\text { / content_5166513.htm (accessed on 12 June 2021)) }\end{array}$ \\
\hline \multirow{5}{*}{ Statistical data } & $\begin{array}{l}\text { Area of land used for transportation } \\
\qquad(2009-2016)\end{array}$ & Text & $\begin{array}{l}\text { Application service platform for the sharing of land } \\
\text { survey results (http:/ / tddc.mnr.gov.cn/to_Login } \\
\text { (accessed on } 2 \text { March 2021)) }\end{array}$ \\
\hline & $\begin{array}{c}\text { Leading industry gross output } \\
\text { value }\end{array}$ & Text & Provincial Statistical Yearbook \\
\hline & Population (2009-2016) & Text & China City Statistical Yearbook (2010-2017) \\
\hline & GDP (2009-2016) & Text & $\begin{array}{c}\text { China City Statistical Yearbook (2010-2017) } \\
\text { Civil Aviation Administration of China }\end{array}$ \\
\hline & Airport throughput (2016) & Text & $\begin{array}{l}\text { (http:/ /www.caac.gov.cn/index.html (accessed on } \\
\text { 8 June 2021)) }\end{array}$ \\
\hline
\end{tabular}


Table 1. Cont.

\begin{tabular}{|c|c|c|c|}
\hline Type & Data & Format & Description \\
\hline \multirow{7}{*}{ Other data } & Urban development planning & Text & $\begin{array}{l}\text { 13th five-year plan for economic and social } \\
\text { development (2016-2020) }\end{array}$ \\
\hline & $\begin{array}{c}\text { Transportation system development } \\
\text { strategy }\end{array}$ & Text & $\begin{array}{l}\text { 13th five-year plan for modern integrated } \\
\text { transportation system development (2016-2020) }\end{array}$ \\
\hline & Industrial development strategy & Text & $\begin{array}{l}\text { 13th five-year plan for strategic emerging industry } \\
\text { development (2016-2020) }\end{array}$ \\
\hline & $\begin{array}{l}\text { National layout plan for highway } \\
\text { hub }(2006-2020)\end{array}$ & Text & $\begin{array}{l}\text { Ministry of Transport of the People's } \\
\text { Republic of China }\end{array}$ \\
\hline & $\begin{array}{l}\text { Harbor Law of the People's } \\
\text { Republic of China (2004) }\end{array}$ & Text & $\begin{array}{l}\text { Ministry of Transport of the People's } \\
\text { Republic of China }\end{array}$ \\
\hline & $\begin{array}{l}\text { Medium and long-term railway } \\
\text { network planning (2016-2025) }\end{array}$ & Text & National Development and Reform Commission \\
\hline & $\begin{array}{l}\text { National layout plan for civil } \\
\text { airports (2006-2020) }\end{array}$ & Text & National Development and Reform Commission \\
\hline
\end{tabular}

\subsection{Design of Decision Support System for Transportation Land Supply}

With the deepening of the concept of sustainable land use, China's land supply pattern has gradually changed from extensive to intensive [59]. To meet the diversified needs of transportation in current and future social and economic development, the strategic focus of the national transportation construction goal should be on obtaining the highest transportation value with the lowest resource consumption. Under the double effects of rigid transportation demand and resource constraints, it is vital for China's land management departments to make the optimal land supply plan for transportation. The Chinese government monopolizes the primary land market and has absolute dominance over the supply of land. Therefore, developing a sustainable land supply strategy will affect the land-use efficiency of the whole country [60]. This paper focuses on the objectives of transportation land supply and has developed a sustainable land supply decision support system that meets the needs of current development of China.

Land used for transportation carries human travel and various economic activities. Population growth and industrial development will lead to a shortage of land used for urban transportation infrastructure. Due to the scarcity and limitation of land, decision makers/planners will inevitably face the challenge of reasonably allocating all kinds of land. For cities with low transportation accessibility and high potential land demand, filling the shortage of land used for transportation and improving the transportation accessibility is the primary task of land supply decisions [61]. In addition, previous studies have shown that the construction of transportation infrastructure can stimulate the development of the regional industrial economy [62]. The transportation sector cannot create benefits separately, which is reflected in its value by supporting other industry sectors. The dependence and type preference of industry sectors on transportation are different, which provides a reference for decision-makers in the land supply structure. For example, resource-intensive industries prefer rail transport, which is suitable for long-distance, large volume, and low pollution risk transportation. Therefore, the supply of land used for transportation in favor of the development needs of urban leading industries determines the future development potential and direction of the city.

The acceleration of China's urbanization process and the extensive land supply policies lead to the oversupply of land in some cities [63]. These cities should improve the utilization efficiency of land used for transportation by tapping into the potential of land use. Population, economy, and ecology are essential effect factors in transportation construction. The coordinated development of social, eco-economic, and transportation is a fundamental and necessary way to improve land-use efficiency. With the proposal of ecological civilization construction, China's land use planning is transformed from the "life and construction priority" to "ecological priority", which reflects China's attention to 
ecological construction in its new stage of development [64]. Therefore, when making land supply decisions, decision-makers should not only consider meeting human production and living needs, but should also consider the constraints of ecological construction on transportation and strictly abide by the red line of ecological protection.

Considering the long-term supply-demand balance of land use, transportation accessibility, the dependence of industry, the preferred transportation mode, and the coordination of social, eco-economic to transportation land supply, the ultimate purpose of this study is to provide a decision-making suggestion for transportation land supply with a clear order and type. When determining the priority of land supply, ensuring the adequacy of reserve land is the premise. The most direct way to alleviate the scarcity of land used for transportation is to increase land supply. Without the guarantee of land area, there is no operational flexibility to improve land-use efficiency. Filling the land shortage, and balancing the benefits of population, economy, ecology, and land use, is an essential part of sustainable development. Clarifying the land supply type in Chinese cities is a further refinement of decision-making. The determination of transportation land supply type is thoroughly combined with urban strategic planning, and leading and emerging industries. Moreover, to validate the reliability of the research results, this paper compares the research results with the city-level, provincial, and national transportation strategic planning (Figure 1).

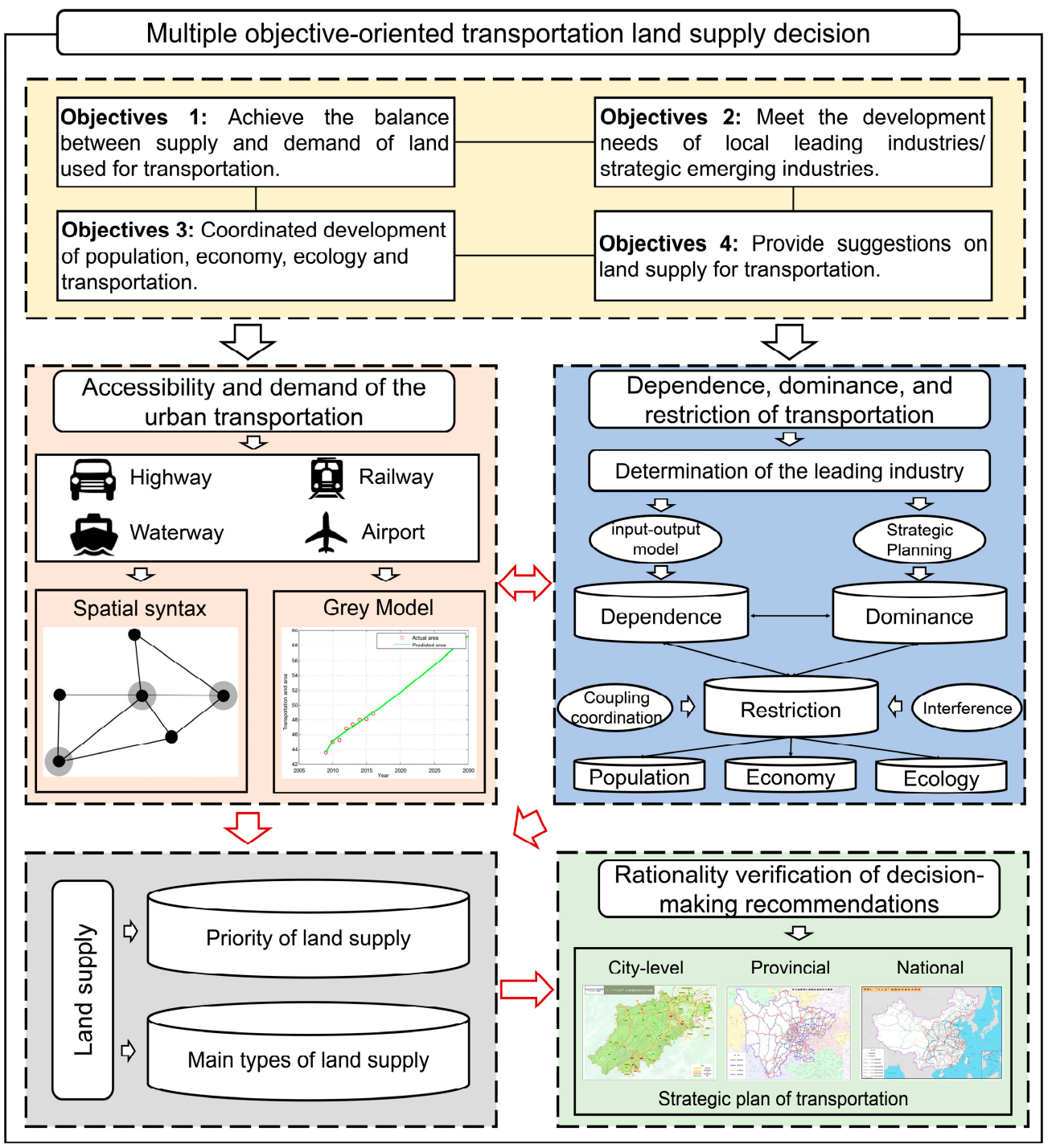

Figure 1. Decision support system of transportation land supply. 


\subsection{Methodology}

\subsubsection{Quantify the Dependence of Urban Development on Transportation}

There is a significant relationship between transportation and industrial development [65], and industry sectors have different levels of dependence on the transportation sector. This paper uses the complete consumption coefficient calculated by the input-output model to determine the dependence of various sectors of the economy on the transportation sector $[66,67]$. The input-output table is from the National Bureau of Statistics. The formula is as follows.

$$
\begin{gathered}
a_{i j}=\frac{x_{i j}}{x_{j}} i, j=1,2, \ldots, n \\
B=(I-A)^{-1}-I A=\left[\begin{array}{cccc}
a_{11} & a_{12} & \ldots & a_{1 n} \\
a_{21} & a_{22} & \ldots & a_{2 n} \\
\vdots & \vdots & \ddots & \vdots \\
a_{n 1} & a_{n 2} & \ldots & a_{n n}
\end{array}\right]
\end{gathered}
$$

where $a_{i j}$ is the amount of product $i$ that is directly consumed by each unit of production $j, x_{j}$ is the output of sector $j, x_{i j}$ is the input of sector $i$ to sector $j, B$ is the complete consumption coefficient matrix, A is the direct consumption coefficient matrix, and I is the unit vector.

This paper then investigates the dependence on transportation by determining the leading industries and strategic emerging industries of different cities. The determination of leading industries and strategic emerging industries mainly refers to the government's public report and industry output value data. The formula is as follows.

$$
\mathrm{D}_{\mathrm{i}}=\frac{\sum_{\mathrm{r}=1}^{\mathrm{n}_{\mathrm{i}}} \mathrm{B}_{\mathrm{ri}}}{\mathrm{n}_{\mathrm{i}}}
$$

where $D_{i}$ is the transportation dependence in i cities, $B_{r i}$ is the complete consumption coefficient of the $r$ sector in $i$ cities, and $n_{i}$ is the number of leading industries and strategic emerging industries in i cities. Moreover, this paper applies the quadrant method to divide Chinese cities into four levels: low (L), lower-middle (LM), higher-middle (HM), and $\operatorname{high}(\mathrm{H})$.

\subsubsection{Determine the Preference of Transportation Mode in Chinese Cities}

The urban preferred transportation mode is determined regarding the strategic transportation plan that has been issued by the Chinese government. More specifically, the determination of highway hub cities refers to 196 cities proposed in the layout planning of national highway transportation hubs. The determination of railway hub cities refers to the general plan of railway hubs issued by the China Railway Corporation. The determination of waterway hub cities refers to the main port cities mentioned in the Port Law of the people's Republic of China. According to the civil aviation airport production statistics bulletin (2017) issued by the Civil Aviation Administration of China, cities with passenger throughput of more than 10 million airports are designated as air transport hub cities. According to the determination principle of the transportation hub, Chinese cities are divided into seven transportation modes in this paper (Figure 2). 


\begin{tabular}{|c|c|c|c|c|c|}
\hline City & 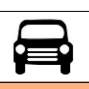 & 曹 & 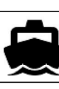 & $A$ & $\begin{array}{c}\text { Transportation } \\
\text { mode }\end{array}$ \\
\hline Beijing & $\sqrt{ }$ & $\sqrt{ }$ & & $\sqrt{ }$ & Integrated \\
\hline Shanghai & $\sqrt{ }$ & $\sqrt{ }$ & $\sqrt{ }$ & $\sqrt{ }$ & Integrated \\
\hline Jining & $\sqrt{ }$ & & $\sqrt{ }$ & & $\mathrm{H}-\mathrm{W}$ \\
\hline Yibin & $\sqrt{ }$ & $\sqrt{ }$ & & & $\mathrm{H}-\mathrm{R}$ \\
\hline Quanzhou & $\sqrt{ }$ & & & $\sqrt{ }$ & $\mathrm{H}-\mathrm{A}$ \\
\hline $\begin{array}{c}\text { Aksu } \\
\text { Prefecture }\end{array}$ & & $\sqrt{ }$ & & $\sqrt{ }$ & R-A \\
\hline Baoding & $\sqrt{ }$ & & & & $\mathrm{H}$ \\
\hline Zhongwei & & $\sqrt{ }$ & & & $\mathrm{R}$ \\
\hline
\end{tabular}

Figure 2. Principles for determining the dominant mode of transportation in Chinese cities. "Integrated" is a city with no less than 3 transportation hubs, " $\mathrm{H}-\mathrm{W}$ " is a city with highway and waterway transportation hubs, "H-A" is a city with highway and air transportation hubs, "R-A" is a city with railway and air transportation hubs, " $\mathrm{H}$ " is a city with highway transportation hubs, and " $\mathrm{R}$ " is a city with railway transportation hubs.

\subsubsection{Response of Socio-Economic Development and Ecological Protection to} Transportation Construction

The coordinated development of socio-economic, ecology and, transportation is a critical path to construct a sustainable transportation system [68]. In this paper, the coupling coordination degree model is used to investigate the interaction between population, economy, and transportation, and the disturbance degree model is used to reflect the impact of transportation construction on ecological protection.

(1) Coupling coordination degree model

The coupling means that two or more systems affect each other by interaction. The degree of coupling reflects the degree of interaction between the systems, and the degree of coordination demonstrates the degree of benign coupling in system interaction. Coupling coordination can determine whether there is coordinated development between systems. The formula can be expressed as follows.

$$
\begin{gathered}
\left\{\mathrm{C}=\left\{\mathrm{U}_{1} \times \mathrm{U}_{2} /\left[\left(\mathrm{U}_{1}+\mathrm{U}_{2}\right) / 2\right]^{2}\right\}^{1 / 2}\right. \\
\mathrm{T}=\alpha \mathrm{U}_{1}+\beta \mathrm{U}_{2} \\
\mathrm{D}=\sqrt{\mathrm{C} \times \mathrm{T}}
\end{gathered}
$$

where $C$ is the coupling degree, $\mathrm{U}_{1}$ and $\mathrm{U}_{2}$ are two interacting subsystems, $\mathrm{T}$ is the comprehensive coordination index of the two subsystems, D is the coupling coordination degree, $\alpha$ and $\beta$ are the weights of subsystems, and this paper sets the same weights of $U_{1}$ and $\mathrm{U}_{2}$. In addition, this paper applies the quadrant method to divide $\mathrm{D}$ to four levels: low (L), lower-middle (LM), higher-middle (HM), and high (H).

(2) Disturbance degree model

The disturbance degree model is applied to quantify the disturbance of the transportation construction on the ecological area. The higher the disturbance, the more frequent transportation activities in the ecological area. The formula is as follows.

$$
\mathrm{W}=\mathrm{LS}
$$

where $\mathrm{W}$ is the degree of disturbance, $\mathrm{L}$ is the length of the road (highway and railway) in the ecological area, and $\mathrm{S}$ is the ecological function area. 


\subsubsection{Grey Prediction of Land Demand for Transportation}

Grey system theory is the control theory of systems with incomplete or uncertain information, which was founded in 1982 [69]. With the development of nearly 40 years, Grey system theory has been widely used in the field of social economy, and it can effectively solve the problems of limited sample size or insufficient information [70]. This paper uses the GM $(1,1)$ model, which is a time series forecasting model [71], to forecast the area demand of land used for transportation in Chinese cities. The formula is as follows.

$$
\hat{\mathrm{x}}^{(1)}(\mathrm{k})=\left(\hat{\mathrm{x}}^{(0)}(1)-\frac{\mathrm{b}}{\mathrm{a}}\right) \mathrm{e}^{-\mathrm{a}(\mathrm{k}-1)}+\frac{\mathrm{b}}{\mathrm{a}}, \mathrm{k}=2, \ldots, \mathrm{n}
$$

where $\hat{\mathrm{x}}^{(0)}$ is the original sequence, $\hat{\mathrm{x}}^{(1)}(\mathrm{k})$ is the original first-order cumulative generation $(1-\mathrm{AGO})$ sequence data fitted value, $\mathrm{k}$ is the time series, and a and $\mathrm{b}$ are model parameters.

To ensure the validity of the grey model, an error test must be carried out. GM $(1,1)$ model error test generally uses a post-test test method. The formula is as follows.

$$
\begin{gathered}
\mathrm{C}=\mathrm{S}_{1} / \mathrm{S}_{0} \\
\mathrm{P}=\mathrm{P}\left(\left|\varepsilon^{(0)}(\mathrm{k})-\bar{\varepsilon}^{(0)}\right|<0.6745 \mathrm{~S}_{0}\right)
\end{gathered}
$$

where $\mathrm{C}$ is a posterior difference ratio, $\mathrm{P}$ is the small error probability, $\mathrm{S}_{0}$ is the variance of the original sequence, $S_{1}$ is the variance of the residuals, and $\varepsilon^{(0)}$ is the residual. When $\mathrm{C}<0.35$ and $\mathrm{P}>0.95$, the model is generally considered to be reliable and the model can be used for forecasting.

\subsubsection{Evaluation of Transportation Accessibility in Chinese Cities}

Spatial syntax is widely used in the accessibility evaluation of urban transportation networks (Table 2). For accessibility analysis with spatial syntax, the road and rail network map should be abstracted into an axis map. The axis is defined as the intersecting line from the starting point to the farthest visible point. In addition, according to the essence of spatial syntactic model, this study is based on two assumptions: ignoring axis attributes and ignoring the influence of topography. Generally, cities are the basic units of daily travel and logistics, so each city is both the starting point and the end point. Therefore, the axis segmentation in this paper adopts the prefecture-level administrative unit as the breakpoint to break the longer axis, and the broken section is regarded as the topological element to complete the expansion of the axis model [72]. The spatial segmentation method used in this paper has been proved to be effective for the analysis of population mobility and large-scale research $[73,74]$.

Existing research generally supports that connection value and integration are the most commonly used and most influential parameters in spatial syntax models [75]. Therefore, this paper uses the connection value to reflect the accessibility of an axis, and the accessibility of the connected axis is measured by local integration [76]. Considering the connection value and integration, the accessibility index based on the spatial syntax model is proposed [77]. The formula is as follows.

$$
\mathrm{A}_{\mathrm{i}}=\sum_{\mathrm{j}=0}^{\mathrm{n}} \mathrm{I}_{\mathrm{j}}
$$

where $A_{i}$ is the accessibility index, $n$ is the number of other axes connected to the $i$ axis, and $I_{j}$ is the local integration of the $j$ axis. 
Table 2. Basic measures of spatial syntax.

\begin{tabular}{ccc}
\hline Index & \multicolumn{1}{c}{ Description } & Formula \\
\hline Connectivity & $\begin{array}{c}\text { Measures the number of neighbor axes directly connected to a } \\
\text { space. It specifies the number of immediate neighbors of an axis. } \\
\text { It is the sum of the inverse values of the parameter connectivity of } \\
\text { all neighbors from the selected axial line. It measures the degree to } \\
\text { which a given space controls access to all immediate neighbors of } \\
\text { the axis line. It considers all alternative connections which these } \\
\text { neighbors have }\end{array}$ & $\mathrm{C}_{\mathrm{i}}=\mathrm{k}$ \\
Control value & $\begin{array}{l}\text { It is defined as the smallest number of syntactic steps (in } \\
\text { topological meaning) that are needed to reach one space from } \\
\text { another. Including global depth, mean depth and local depth. } \\
\text { Integration is a variable that refers to how a space is connected with } \\
\text { other spaces in its surroundings. This is the key parameter to } \\
\text { understand the relationships that exist between users and the urban } \\
\text { space and it is a global measure. Including global integration and } \\
\text { lntegration }\end{array}$ & $\mathrm{I}_{\mathrm{i}}=\frac{\mathrm{m}-2}{2(\overline{\mathrm{D}}-1)} \mathrm{LI}_{\mathrm{i}}=\frac{\mathrm{m}\left[\log _{2}-\frac{\mathrm{m}+2}{3}-1\right]+1}{(\mathrm{~m}-1)(\overline{\mathrm{D}}-1)}$ \\
\hline
\end{tabular}

\section{Results}

\subsection{The Dominant Mode of Transportation in Chinese Cities}

Nearly two thirds of China's prefecture-level cities are dominated by a single transportation mode and these cities are mainly distributed in central and western China (Figure 3). Moreover, more than $80 \%$ of the single transportation mode cities are dominated by highway transportation, reflecting the critical position of highway transportation in China's transportation system. Air and waterway transportation is restricted by geographical conditions and thus are unlikely to become universal transportation modes, but they are still essential components of the transportation system of some cities. Cities dominated by integrated transportation are mainly located in the eastern coastal area, and these cities are mainly economically developed and densely populated. "H-A mode" cities are primarily distributed in central and western China, such as Lijiang, Xishuangbanna Dai Autonomous Prefecture, Zhangjiajie, and Yanbian Korean Autonomous Prefecture. These cities are generally economically backward and limited by geographical conditions; it is difficult to carry out railway construction, and air transportation has become an important transportation mode for economic development. "H-W mode" cities are mainly distributed in coastal areas and the Yangtze, Yellow, and Pearl River basins, such as Zhoushan, Jingzhou, Qinhuangdao, Rizhao and Shantou. "H-R mode" cities are mainly provincial sub-central cities and emerging cities with high development potential, such as Tangshan, Luoyang, Baoji, Jiuquan, Tongliao, and Huaihua.

\subsection{Analysis on the Dependence of Transportation in Chinese Cities}

More than 200 cities have high and higher-middle levels of dependence on transportation, reflecting that transportation infrastructure plays an essential role in China's economic growth and industrial development (Figure 4). Cities with high dependence on transportation are mainly concentrated in central and eastern China, and the development of leading industries in these cities needs strong support from the transportation sector. Cities with low and lower-middle levels of dependence on transportation are mainly distributed in western China. Most of these cities' leading industries are dominated by agriculture and animal husbandry. It is worth noting that some cities in the west border areas of China are highly dependent on transportation, such as Kashgar, Hotan, Ngari, Bayingoleng Mongolian Autonomous Prefecture, and Altay. Moreover, Kashgar is the only city with high transportation dependence in Xinjiang. The main reason for Kashgar's high dependence on transportation is that it is the economic growth pole of Xinjiang, and it is the industrial base of the textile industry, metallurgical industry, petrochemical industry, international trade logistics industry, tourism and agricultural and sideline products processing industry in the 
western region, and these industries are highly dependent on the support of transportation sector.

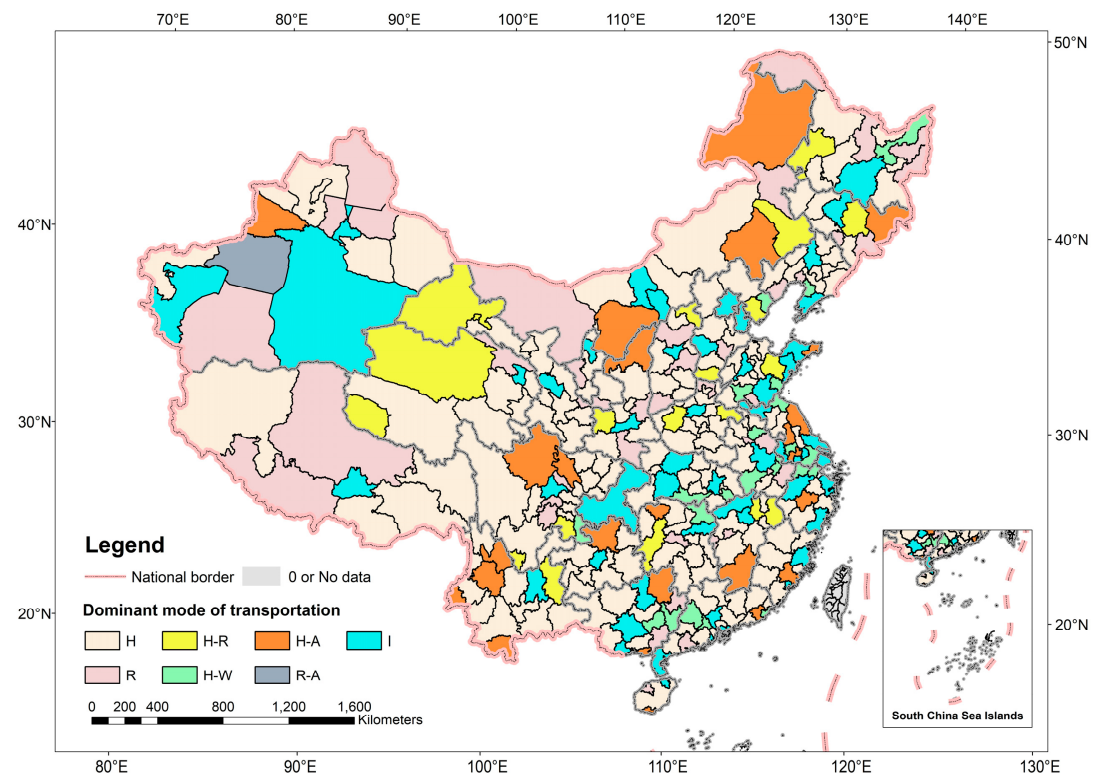

Figure 3. Dominant mode of transportation in prefecture-level cities.

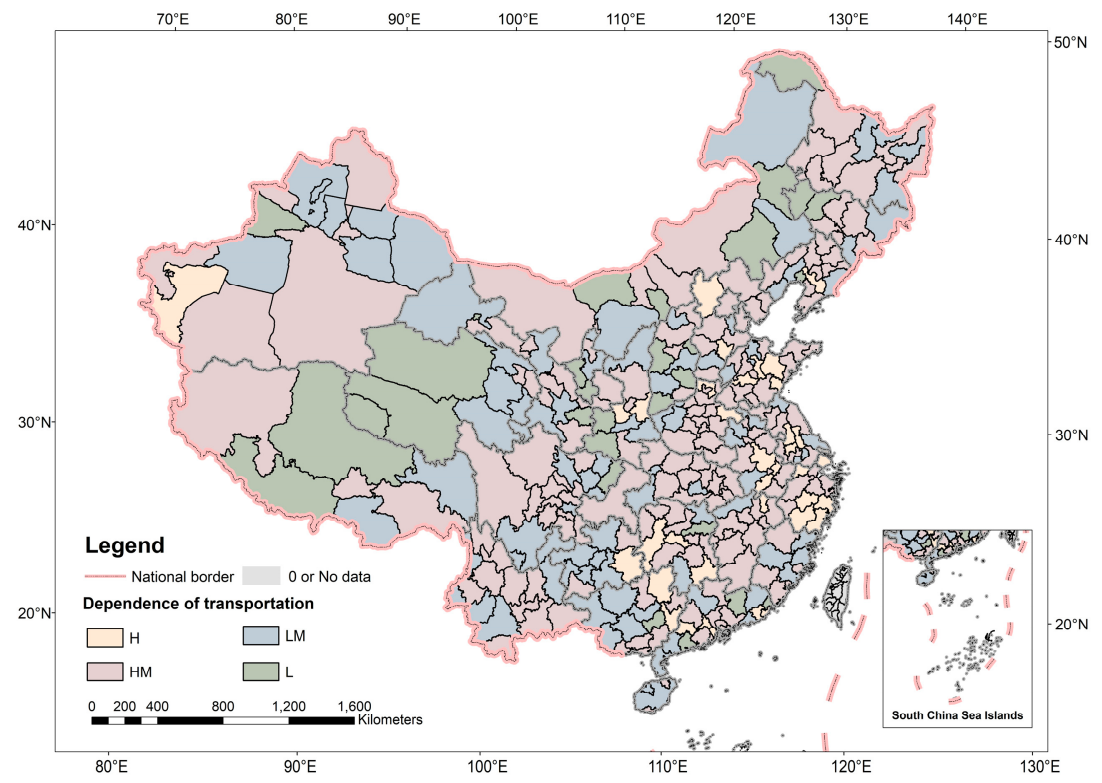

Figure 4. Transportation dependence of prefecture-level cities.

\subsection{The Response of Social and Eco-Economic to the Land Demand for Transportation}

The coupling coordination degree of population and transportation in Chinese cities presents the spatial distribution characteristics of high in the east and low in the west, which is consistent with the spatial distribution of population density in China (Figure 5). Cities with high coupling and coordination of economy and transportation are mainly distributed in provincial capital cities, provincial sub-central cities, and emerging cities. The coupling coordination of economy, population, and transportation present similar spatial distribution characteristics, reflecting the positive response between transportation construction, economic development, and population aggregation. However, a few cities show a lack of coordination between the population and economy, such as Hulunbuir, Ordos, and Jieyang. The cities in the western and northeastern parts of China are less 
disturbed by transportation activities. The cities in the central and eastern parts of China have experienced frequent infrastructure construction activities.

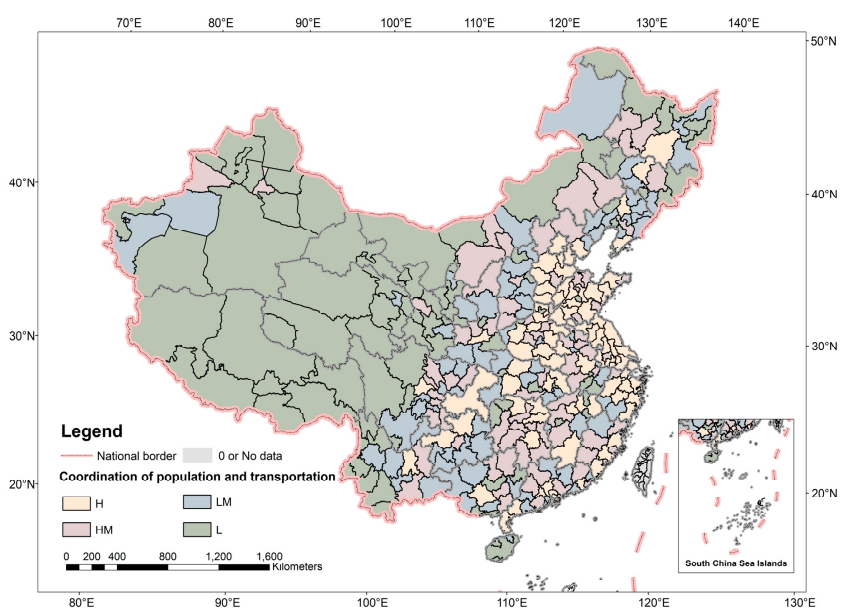

(a)

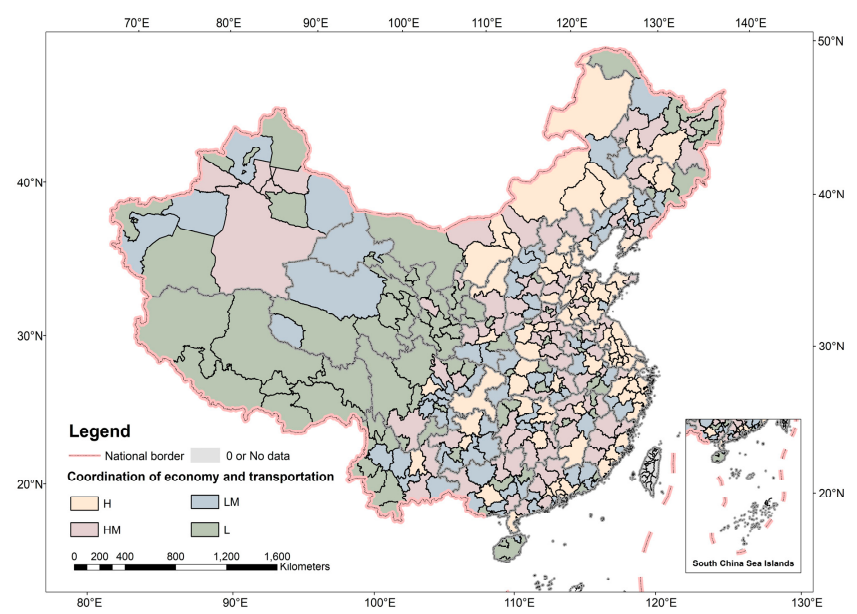

(b)

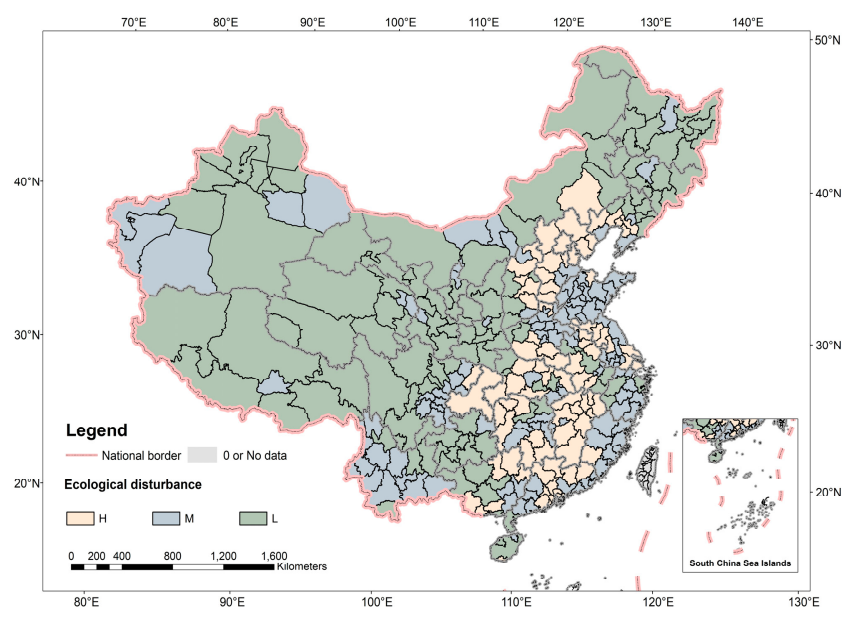

(c)

Figure 5. Coordination between population, economy, ecology and transportation. (a) Coordination of population and transportation; (b) coordination of economy and transportation; (c) ecological disturbance caused by transportation construction.

\subsection{Analysis of the Accessibility of the Transportation Network in Chinese Cities}

The transportation accessibility of Chinese cities presents the spatial distribution characteristic of high in the northeast and low in the southwest, similar to the spatial distribution characteristics of population density in China (Figure 6). Most cities with high transportation accessibility are provincial capitals and municipalities directly under the central government, and these cities are China's comprehensive transportation hubs. Beijing is the city with the highest accessibility of transportation in China, which is closely related to Beijing's political and economic status. In addition, cities with high transportation accessibility show apparent spatial aggregation, mainly distributed in the Jing-Jin-Ji urban circle, Yangtze river delta urban agglomerations, Pearl river delta urban agglomeration, central plains economic region, and Chengdu-Chongqing economic circle. The accessibility of transportation in western cities is generally low, mainly limited by geographical conditions. The transportation accessibility of 11 cities is 0 , including Shuangyashan, Daxing'anling Prefecture, Huanggang, Sansha, Honghe Hani and Yi Autonomous Prefecture, 
Wenshan Zhuang and Miao Autonomous Prefecture, Nujiang Lisu Autonomous Prefecture, Shannan region, Huangnan Tibetan Autonomous Prefecture, Hainan Tibetan Autonomous Prefecture, and Bortala Mongol Autonomous Prefecture.

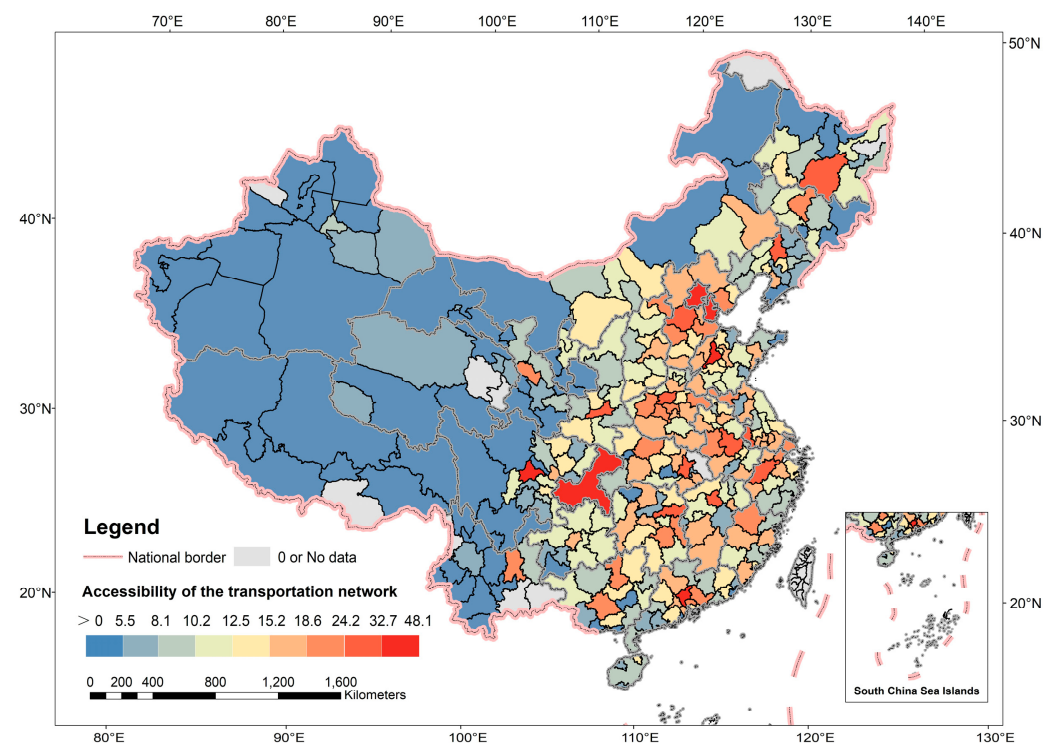

Figure 6. Transportation accessibility in Chinese cities.

\subsection{Land Demand Forecast for Chinese Cities in 2025}

The focus of China's transportation infrastructure construction is gradually shifting from the east to the central and western regions, and prosperous infrastructure construction activities will bring huge land demand. Cities with high land demand for transportation are mainly distributed in west and central China, and cities with high land demand for transportation are mainly divided into two types: municipalities directly under the central government and provincial capital cities, and cities with high development potential in western China (Figure 7). Municipalities directly under the central government and provincial capital cities have relatively complete transportation systems, but the rapid economic development and population migration still bring tremendous transportation pressure. For example, Chongqing has the highest land demand for transportation; it is an important transportation hub in the southwestern region of China, as well as the most populous city. Due to the weak transportation infrastructure of emerging cities in western China, it is necessary to increase land supply to meet development needs. Cities with low land demand for transportation are mainly underdeveloped cities in the northeast and west China. In addition, the construction of transportation infrastructure has slowed down in some third- and fourth-tier cities in eastern China, such as Huangshan, Lishui, Zhenjiang, and Jining.

\subsection{Decision Making of Transportation Land Supply in Chinese cities}

Cities that need to be prioritized for transportation land supply are mostly nonprovincial capital cities and are the growth poles of regional economic development (Figure 8). The top ten cities in transportation land supply priority are Kashgar, Qiandongnan Miao and Dong Autonomous Prefecture, Wenzhou, Xianyang, Wuhu, Hefei, Zhangjiakou, Nyingchi, Alxa League, and Xilingol League. The main characteristics of cities with low land supply priority are sparse population, good ecological condition, and being far away from the core area of economic development, such as Songyuan, Jiayuguan, Nagqu, Rikaze, and Daxing'anling Prefecture. Moreover, cities with integrated land supply modes generally have higher land supply priority, and these cities are promoting the construction of a comprehensive three-dimensional transportation systems. Cities with high land supply priority in the western region are generally dominated by a single transportation mode, 
mainly due to the weak transportation infrastructure in the west region and the difficulty in developing a comprehensive transportation system in the short term.

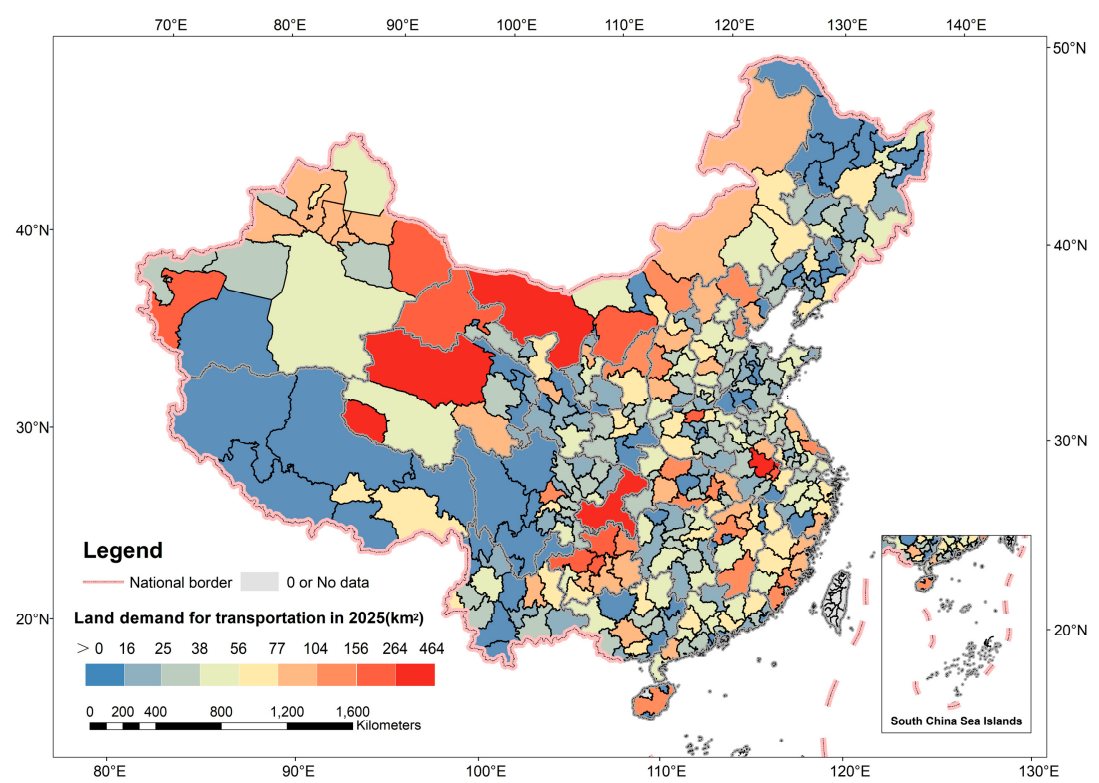

Figure 7. Land demand forecast for transportation in Chinese cities.

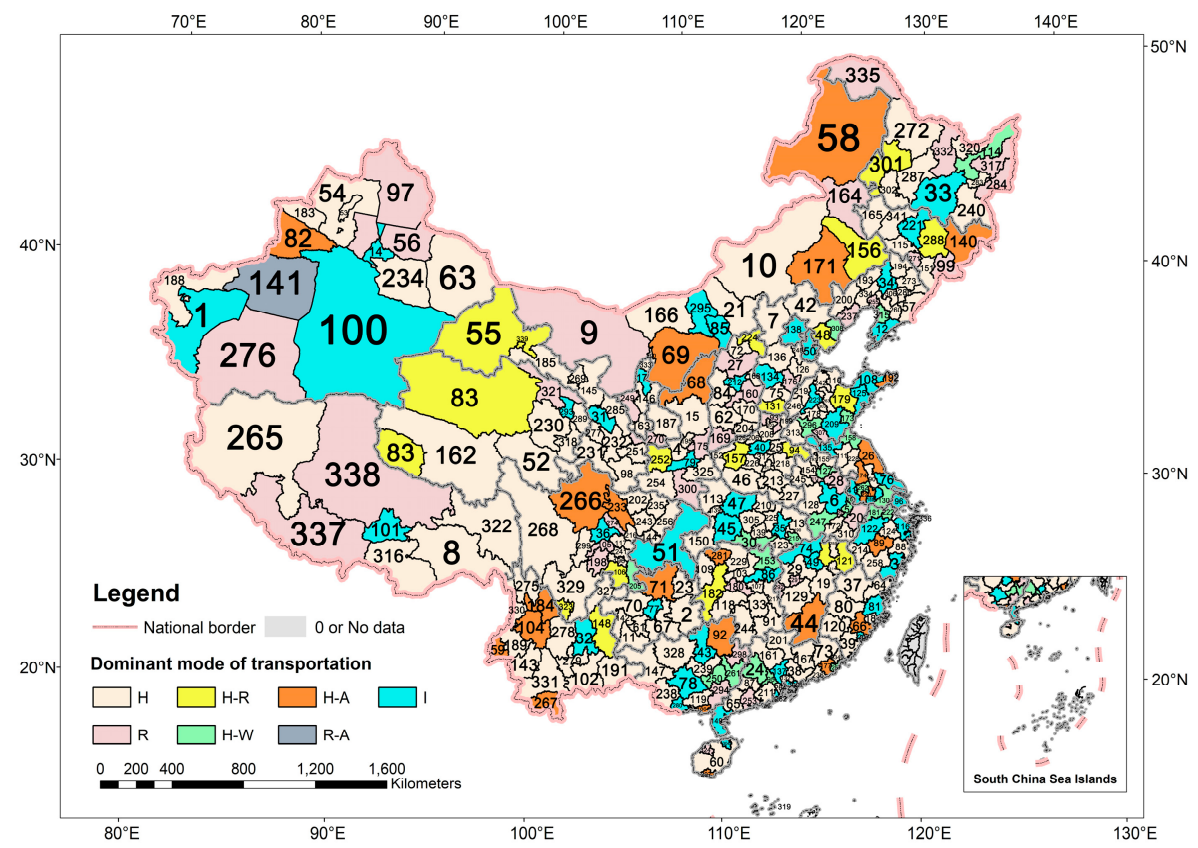

Figure 8. Priority and type of land supply for urban transportation (the Arabic numerals represent the recommended order of land supply).

\section{Discussion}

\subsection{Reliability Validation of Transportation Land Supply Strategy in Chinese Cities}

Since the government has not issued a specific plan on the allocation of land used for transportation, this paper refers to the national, provincial, and city-level transportation strategic plan to validate the reliability of the research results. The verification results indicate that the cities with high priority of land supply proposed in this paper are the key construction cities of China's transportation infrastructure. For example, the outline of the national comprehensive three-dimensional transportation network planning recently released by the Chinese government points out that Kashgar is an essential group for 
building the national comprehensive three-dimensional transportation network. It is one of the critical border channels. The Chinese government has planned to build roads and railways in Kashgar and build Kashgar into an aviation hub. Moreover, according to the 13th five-year plan for transportation development, Qiandongnan Miao and Dong Autonomous Prefecture have planned to build $953 \mathrm{~km}$ of expressways and 16 general airports from 2015 to 2020. The total capital needed for transportation infrastructure construction is about 217.5 billion yuan, which has doubled compared with the 12th five-year plan period. Cities with a low priority of transportation land supply have a low strategic position in national transport planning, and few major transportation infrastructure projects are planned to be built in the short term in these cities.

\subsection{Implications and Applications}

Land used for transportation is an integral part of the land use classification system, and the primary function of transportation infrastructure is the link connecting cities and the channel for population flow and material circulation [78]. The allocation of land used for transportation refers to the allocation of different types of transportation infrastructure to different regions in a certain period. The purpose is to effectively meet the passenger and freight transportation needs generated by economic and social development. Therefore, the optimal allocation of land used for transportation greatly affects the quality of life and production capacity. Few studies have focused on the optimal allocation of land used for transportation, and there is no research on the supply decision of land used for urban transportation at the national scale. In this paper, the multiple objective-oriented decision of transportation land supply is proposed by comprehensively considering various factors that affect transportation construction. The research results of this paper provide a decisionmaking reference for the land management department to improve land- use efficiency, and the ultimate goal is to achieve sustainable transportation development.

For the land management department, it is of great significance to investigate the development of leading industries and strategic emerging industries in a city, which is an essential way to reasonably allocate land used for transportation on a large scale. Leading industries affect the speed and volume of urban economic growth, and emerging industries affect the inner potential of urban economic development [79]. Therefore, the industrial development direction of a city has a significant impact on its preference for transportation modes and its dependence on transportation. For example, resource-based cities generally have a higher dependence on transportation, while agriculture-based cities have typically lower dependence on transportation. For developed cities with relatively stable industrial structures, the land supply idea should change to high land-use efficiencies, such as Beijing, Shanghai, and Hangzhou. The economic development of emerging cities, such as Chengdu, Guiyang, and Xiangyang, is in the stage of rapid rise, and the development and transformation of industries need the support of large-scale transportation infrastructure construction. In addition, the land use demand forecast for transportation is another important path to reasonably allocate land used for transportation on a large scale. Reasonable land use demand forecasting can more intuitively show which cities are in urgent need of land supply [80]. The growth rate of land used for urban transportation in recent years can reflect the demand for land areas devoted to transportation for urban development. From 2009 to 2016, the land area devoted to transportation of 27 cities at least doubled, and most cities are distributed in the central and western regions, which reflects the increasing construction of transportation infrastructure in west and central China in recent years. Moreover, transportation accessibility analysis is a crucial method to characterize the current situation of urban transportation development [52]. Cities with low transportation accessibility should be paid more attention to by land management departments. The construction of transportation infrastructure in these cities is also an important part of building a comprehensive three-dimensional transportation network in China.

The land supply strategy of the transportation sector is not to expand the land area in a disorderly fashion; the oversupply of land will lead to the imbalance of urban de- 
velopment [81]. The coordinated development of social and eco-economic benefits and transportation demand is the ultimate objective to realize sustainable transportation [82]. Therefore, the land management department should fully consider the social, economic, and ecological conditions of the city when formulating the land supply plan. More than half of China's cities are still in the uncoordinated development of transportation and social economy, reflecting the unbalanced allocation of land used for transportation. In addition, with the Chinese government vigorously carrying out the construction of ecological civilization, the decision-making of land supply must consider the negative impact of transportation infrastructure construction on ecological protection [83]. China's central and local governments have defined the scope of the ecological conservation redline and stipulated that production and construction activities are prohibited in the ecological conservation core area [84]. To maintain national ecological security, the construction of urban transportation infrastructure must avoid destroying habitat and endangering biodiversity.

\subsection{Limitations and Prospects}

The research on sustainable land use from multiple scales is an important task in the future. The purpose of this paper is to recommend to decision-makers at the macro scale where to supply land and what type of transportation infrastructure to build. However, the transportation land supply decision-making system constructed in this paper does not consider the interaction between land-use types. Therefore, this paper cannot determine the accurate land demand area and spatial location of each city, which needs to be further supported by specific land use and transportation planning.

Improving the accuracy of land demand forecasting on a large scale is another important topic in future research. It is a common method to use the trend of historical data to forecast future data. However, due to the dynamics of the development situation and the limitations of official data, the land demand forecasting in this paper is uncertain. Therefore, it is expected that there are some differences between the results of this paper and national planning. However, the research results of this paper are consistent with the direction of China's transportation strategic planning. The unified forecasting method can be used for the horizontal comparative study of Chinese cities and is suitable for large-scale land supply decision-making. In addition, the simulation analysis of the land supply suggestions proposed in this paper is the direction of further research, which can more intuitively reflect the effectiveness of the research achievements of this paper.

\section{Conclusions}

Intensive and efficient land use is a meaningful way to realize sustainable development. The development of transportation is affected by population, economy, industrial development, ecological protection, and national macro-control. The decision-making of land supply is a process in which multiple influencing factors are in coordination. By comprehensively considering transportation dependence, dominant transportation modes, coordination of economic, population, and ecology on the development of transportation, transportation accessibility, and potential land demand for transportation, this paper constructed a land supply decision support system under multi-objective guidance, which provides an essential reference for Chinese decision-makers to formulate targeted land use planning.

The results of this paper show that there are apparent differences in dependence, dominance, coordination, accessibility, and potential demand of transportation in Chinese cities. Specifically, more than $70 \%$ of Chinese cities are dominated by land transportation, and roads are the universal mode of transportation. The transportation modes of municipalities directly under the central government, provincial capitals, or cities with geographical advantages are diversified, reflecting that China's core cities have initially formed a comprehensive transportation system. Transportation is an essential driving force to promote industrial development. Nearly two thirds of Chinese cities have a high and higher-middle level of dependence on transportation. Cities with low dependence 
on transportation mainly rely on agriculture and animal husbandry as the main driving force of economic development. More than half of China's cities are uncoordinated in terms of population, economy, and transportation, and uncoordinated cities are mainly distributed in western China. The disturbance degree of transportation to ecological space presents as high in the east and low in the west. Transportation accessibility shows obvious spatial aggregation. Cities with high transportation accessibility are mainly concentrated in major urban agglomerations in China. Except for municipalities directly under the central government and provincial capital cities, cities with high land demand for transportation are mostly the economic development growth pole and emerging cities in west and central China.

The main achievement of this paper is to comprehensively consider multiple objectives in the decision-making of transportation land supply, and it investigates where the land supply is urgently needed and what type of transportation infrastructure is focused on construction. The results of this paper indicate that the cities with high priority of land supply are mostly non-provincial cities with good economic development, which are the important growth poles of regional development. These cities are promoting the construction of comprehensive three-dimensional transportation systems, as the land used for transportation is in seriously short supply. Cities with low land supply priority are generally sparsely populated, in good ecological condition, and far away from the core area of economic development. The land supplied for transportation is mainly used for the construction of land transportation. The research results provide general experience in transportation land supply for land management departments and improve the pertinence of land allocation from a macro perspective. In addition, the research ideas of this paper are generally applicable to the transportation land supply decision-making of countries, regions, provinces, and urban agglomerations and have reference value for the formulation of large-scale land-use planning and transportation development strategies.

Author Contributions: Conceptualization, J.Z. and K.W.; methodology, J.Z. and K.W.; software, K.W.; validation, K.W. and D.Z.; formal analysis, K.W. and X.W.; data curation, K.W. and D.Z.; writingoriginal draft preparation, K.W.; writing - review and editing, K.W. and J.Z.; visualization, K.W. and D.Z.; supervision, J.Z.; project administration, J.Z.; funding acquisition, J.Z. All authors have read and agreed to the published version of the manuscript.

Funding: This research was funded by the Research Funds for Information Center of the Ministry of Natural Resources of the People's Republic of China (Grant Number: 2018-34-0106-14), the Fundamental Research Funds for the Central Universities.

Data Availability Statement: The data presented in this study are available upon request from the corresponding author.

Acknowledgments: The authors would like to thank the anonymous reviewers for their comments and suggestions.

Conflicts of Interest: The authors declare no conflict of interest.

\section{References}

1. Pérez-Soba, M.; Petit, S.; Jones, L.; Bertrand, N.; Briquel, V.; Omodei-Zorini, L.; Contini, C.; Helming, K.; Farrington, J.H.; Mossello, M.T; et al. Land use functions-A multifunctionality approach to assess the impact of land use changes on land use sustainability. In Sustainability Impact Assessment of Land Use Changes; Helming, K., Pérez-Soba, M., Tabbush, P., Eds.; Springer: Berlin/Heidelberg, Germany, 2008; pp. 375-404.

2. Koczberski, G.; Curry, G.N. Making a living: Land pressures and changing livelihood strategies among oil palm settlers in Papua New Guinea. Agric. Syst. 2005, 85, 324-339. [CrossRef]

3. Li, B.; Cao, X.; Xu, J.; Wang, W.; Ouyang, S.; Liu, D. Spatial-Temporal Pattern and Influence Factors of Land Used for Transportation at the County Level since the Implementation of the Reform and Opening-Up Policy in China. Land 2021, 10, 833. [CrossRef]

4. Loveland, T.R.; Reed, B.C.; Brown, J.F.; Ohlen, D.O.; Zhu, Z.; Yang, L.; Merchant, J.W. Development of a global land cover characteristics database and IGBP DISCover from $1 \mathrm{~km}$ AVHRR data. Int. J. Remote Sens. 2000, 21, 1303-1330. [CrossRef]

5. Anderson, J.R. A Land Use and Land Cover Classification System for Use with Remote Sensor Data; US Government Printing Office: Washington, DC, USA, 1976; Volume 964. 
6. Zhao, P.; Lü, B.; de Roo, G. Urban Expansion and Transportation: The Impact of Urban form on Commuting Patterns on the City Fringe of Beijing. Environ. Plan. A Econ. Space 2010, 42, 2467-2486. [CrossRef]

7. Vande Walle, S.; Steenberghen, T.; Paulley, N.; Pedler, A.; Martens, M. The role of indicators in the assessment of integrated land-use and transport policies in European cities. Int. Plan. Stud. 2004, 9, 173-196. [CrossRef]

8. Okraszewska, R.; Romanowska, A.; Wołek, M.; Oskarbski, J.; Birr, K.; Jamroz, K. Integration of a Multilevel Transport System Model into Sustainable Urban Mobility Planning. Sustainability 2018, 10, 479. [CrossRef]

9. Mendez, V.M.; Monje, C.A.; White, V. Beyond Traffic: Trends and Choices 2045-A National Dialogue About Future Transportation Opportunities and Challenges; Springer International Publishing: Berlin/Heidelberg, Germany, 2017.

10. Keong, C.K.; Grace, O. Smart Mobility 2030-ITS Strategic Plan for Singapore. Land Transport Authority of Singapore. 2015. Available online: https:/ / esci-ksp.org/wp/wp-content/uploads/2012/06/J15Nov_p04Chin_SmartMobility2030.pdf (accessed on 26 December 2021).

11. Jin, F.; Ding, J.; Wang, J.e.; Liu, D.; Wang, C. Transportation development transition in China. Chin. Geogr. Sci. 2012, 22, 319-333. [CrossRef]

12. Sun, J.D.; Shen, L.F.; Peng, W. Regional Evaluation of the Transportation Infrastructure Construction Level in China. Appl. Mech. Mater. 2013, 275-277, 2777-2783. [CrossRef]

13. Shen, L.; Du, L.; Yang, X.; Du, X.; Wang, J.; Hao, J. Sustainable Strategies for Transportation Development in Emerging Cities in China: A Simulation Approach. Sustainability 2018, 10, 844. [CrossRef]

14. Banerjee, A.; Duflo, E.; Qian, N. On the road: Access to transportation infrastructure and economic growth in China. J. Dev. Econ. 2020, 145, 102442. [CrossRef]

15. Canning, D.; Pedroni, P. The effect of infrastructure on long run economic growth. Harv. Univ. 2004, 99, 1-30.

16. Gillen, D.W. Transportation infrastructure and economic development: A review of recent literature. Logist. Transp. Rev. 1996, 32, 39.

17. Herrendorf, B.; Schmitz, J.J.A.; Teixeira, A. The role of transportation in US economic development: 1840-1860. Int. Econ. Rev. 2012, 53, 693-716. [CrossRef]

18. Magazzino, C.; Mele, M. On the relationship between transportation infrastructure and economic development in China. Res. Transp. Econ. 2020, 100947. [CrossRef]

19. Craven, J.; Horan, E.; Goulding, R. Population growth and infrastructure development in Melbourne. WIT Trans. Ecol. Environ. 2014, 191, 509-520. [CrossRef]

20. Li, Y.; DaCosta, M.N. Transportation and income inequality in China: 1978-2007. Transp. Res. Part A Policy Pract. 2013, 55, 56-71. [CrossRef]

21. Gramlich, E.M. Infrastructure investment: A review essay. J. Econ. Lit. 1994, 32, 1176-1196.

22. Song, M.; Wang, S.; Fisher, R. Transportation, iceberg costs and the adjustment of industrial structure in China. Transp. Res. Part D Transp. Environ. 2014, 32, 278-286. [CrossRef]

23. Teye, V.B. Land transportation and tourism in Bermuda. Tour. Manag. 1992, 13, 395-405. [CrossRef]

24. Sobieralski, J.B. Transportation infrastructure and employment: Are all investments created equal? Res. Transp. Econ. 2020, 100927. [CrossRef]

25. Liu, T.-Y.; Su, C.-W. Is transportation improving urbanization in China? Socio-Econ. Plan. Sci. 2021, 77, 101034. [CrossRef]

26. Pradhan, R.P.; Arvin, M.B.; Nair, M. Urbanization, transportation infrastructure, ICT, and economic growth: A temporal causal analysis. Cities 2021, 115, 103213. [CrossRef]

27. Kasraian, D.; Maat, K.; Stead, D.; van Wee, B. Long-term impacts of transport infrastructure networks on land-use change: An international review of empirical studies. Transp. Rev. 2016, 36, 772-792. [CrossRef]

28. Paulley, N.; Balcombe, R.; Mackett, R.; Titheridge, H.; Preston, J.; Wardman, M.; Shires, J.; White, P. The demand for public transport: The effects of fares, quality of service, income and car ownership. Transp. Policy 2006, 13, 295-306. [CrossRef]

29. Jiang, X.; Zhang, L.; Xiong, C.; Wang, R. Transportation and Regional Economic Development: Analysis of Spatial Spillovers in China Provincial Regions. Netw. Spat. Econ. 2016, 16, 769-790. [CrossRef]

30. Steinhäußer, R.; Siebert, R.; Steinführer, A.; Hellmich, M. National and regional land-use conflicts in Germany from the perspective of stakeholders. Land Use Policy 2015, 49, 183-194. [CrossRef]

31. Shaw, S.-L.; Xin, X. Integrated land use and transportation interaction: A temporal GIS exploratory data analysis approach. J. Transp. Geogr. 2003, 11, 103-115. [CrossRef]

32. Ma, Z.; Li, C.; Zhang, J. Transportation and Land Use Change: Comparison of Intracity Transport Routes in Changchun, China. J. Urban Plan. Dev. 2018, 144, 05018015. [CrossRef]

33. Waddell, P.; Ulfarsson, G.F.; Franklin, J.P.; Lobb, J. Incorporating land use in metropolitan transportation planning. Transp. Res. Part A Policy Pract. 2007, 41, 382-410. [CrossRef]

34. Ewing, R.; Meakins, G.; Bjarnson, G.; Hilton, H. Transportation and Land Use. In Making Healthy Places: Designing and Building for Health, Well-being, and Sustainability; Dannenberg, A.L., Frumkin, H., Jackson, R.J., Eds.; Island Press/Center for Resource Economics: Washington, DC, USA, 2011; pp. 149-169.

35. Lee, D. An Efficient Transportation and Land Use System; US Department of Transportation: Cambridge, MA, USA, 1989.

36. Levine, J.; Frank, L.D. Transportation and land-use preferences and residents' neighborhood choices: The sufficiency of compact development in the Atlanta region. Transportation 2007, 34, 255-274. [CrossRef] 
37. Demirel, H.; Sertel, E.; Kaya, S.; Zafer Seker, D. Exploring impacts of road transportation on environment: A spatial approach Desalination 2008, 226, 279-288. [CrossRef]

38. Lu, H.; Wang, J.; Yuan, H. Study of Optimal Urban Land-use Pattern Based on Transportation Efficiency. China J. Highw. Transp. 2005, 18, 109-113.

39. Atash, F. Reorienting metropolitan land use and transportation policies in the USA. Land Use Policy 1996, 13, 37-49. [CrossRef]

40. Litman, T. Evaluating transportation land use impacts. World Transp. Policy Pract. 1995, 1, 9-16. [CrossRef]

41. Yaliniz, P.; Bilgic, S.; Vitosoglu, Y.; Turan, C. Evaluation of urban public transportation efficiency in Kutahya, Turkey. Procedia-Soc. Behav. Sci. 2011, 20, 885-895. [CrossRef]

42. Liu, Y.; Zhang, Z.; Zhou, Y. Efficiency of construction land allocation in China: An econometric analysis of panel data. Land Use Policy 2018, 74, 261-272. [CrossRef]

43. Shibusawa, H. Agglomeration of the Firms and the Allocation of Land to the Transportation in the Information-oriented City. Stud. Reg. Sci. 1993, 23, 37-61. [CrossRef]

44. Sevcikova, H.; Nichols, B. Land use uncertainty in transportation forecast. J. Transp. Land Use 2021, 14, 805-820. [CrossRef]

45. Harahap, F.; Silveira, S.; Khatiwada, D. Land allocation to meet sectoral goals in Indonesia-An analysis of policy coherence. Land Use Policy 2017, 61, 451-465. [CrossRef]

46. Williamson, I.; Enemark, S.; Rajabifard, A. Land Administration for Sustainable Development; ESRI Press Academic: Redlands, CA, USA, 2009

47. Eastman, J.R.; Jiang, H.; Toledano, J. Multi-criteria and multi-objective decision making for land allocation using GIS. In Multicriteria Analysis for Land-Use Management; Beinat, E., Nijkamp, P., Eds.; Springer: Dordrecht, The Netherlands, 1998; pp. 227-251.

48. Strauch, M.; Cord, A.F.; Pätzold, C.; Lautenbach, S.; Kaim, A.; Schweitzer, C.; Seppelt, R.; Volk, M. Constraints in multi-objective optimization of land use allocation-Repair or penalize? Environ. Model. Softw. 2019, 118, 241-251. [CrossRef]

49. Wang, X.; Yu, S.; Huang, G.H. Land allocation based on integrated GIS-optimization modeling at a watershed level. Landsc. Urban Plan. 2004, 66, 61-74. [CrossRef]

50. Cui, X.; Fang, C.; Wang, Z.; Bao, C. Spatial relationship of high-speed transportation construction and land-use efficiency and its mechanism: Case study of Shandong Peninsula urban agglomeration. J. Geogr. Sci. 2019, 29, 549-562. [CrossRef]

51. Bartholomew, K. Land use-transportation scenario planning: Promise and reality. Transportation 2007, 34, 397-412. [CrossRef]

52. Su, H.; Wu, J.H.; Tan, Y.; Bao, Y.; Song, B.; He, X. A land use and transportation integration method for land use allocation and transportation strategies in China. Transp. Res. Part A Policy Pract. 2014, 69, 329-353. [CrossRef]

53. Lopes, S.B.; Brondino, N.C.; Rodrigues da Silva, A.N. GIS-Based Analytical Tools for Transport Planning: Spatial Regression Models for Transportation Demand Forecast. ISPRS Int. J. Geo-Inf. 2014, 3, 565. [CrossRef]

54. Koomen, E.; Borsboom-van Beurden, J. Land-Use Modelling in Planning Practicenull; Springer Nature: Basingstoke, UK, 2011.

55. Iacono, M.; Levinson, D.; El-Geneidy, A.; Wasfi, R. A Markov chain model of land use change. TeMA J. Land Use Mobil. Environ. 2015, 8, 263-276.

56. Li, Z.; Tong, Q.; Wang, R. An Optimized Combination Model for Construction Land Increasing Trend Forecasting; SPIE: Bellingham, WA, USA, 2007; Volume 6753.

57. Shepherd, S.P. A review of system dynamics models applied in transportation. Transp. B Transp. Dyn. 2014, 2, 83-105. [CrossRef]

58. Pijanowski, B.C.; Brown, D.G.; Shellito, B.A.; Manik, G.A. Using neural networks and GIS to forecast land use changes: A Land Transformation Model. Comput. Environ. Urban Syst. 2002, 26, 553-575. [CrossRef]

59. Geng, B.; Zheng, X.; Fu, M. Scenario analysis of sustainable intensive land use based on SD model. Sustain. Cities Soc. 2017, 29, 193-202. [CrossRef]

60. Liu, Y.; Fang, F.; Li, Y. Key issues of land use in China and implications for policy making. Land Use Policy 2014, 40, 6-12. [CrossRef]

61. Xu, W.; Yang, L. Evaluating the urban land use plan with transit accessibility. Sustain. Cities Soc. 2019, 45, 474-485. [CrossRef]

62. Lee, M.-K.; Yoo, S.-H. The role of transportation sectors in the Korean national economy: An input-output analysis. Transp. Res. Part A Policy Pract. 2016, 93, 13-22. [CrossRef]

63. Jiang, Y.; Mohabir, N.; Ma, R.; Zhu, P. Sorting through Neoliberal Variations of Ghost Cities in China. Land Use Policy 2017, 69, 445-453. [CrossRef]

64. Gu, Y.; Wu, Y.; Liu, J.; Xu, M.; Zuo, T. Ecological civilization and government administrative system reform in China. Resour. Conserv. Recycl. 2020, 155, 104654. [CrossRef]

65. Button, K.J.; Leitham, S.; McQuaid, R.W.; Nelson, J.D. Transport and industrial and commercial location. Ann. Reg. Sci. 1995, 29, 189-206. [CrossRef]

66. Leontief, W. Input-Output Economics; Oxford University Press: Oxford, UK, 1986.

67. Chiu, R.-H.; Lin, Y.-C. Applying input-output model to investigate the inter-industrial linkage of transportation industry in Taiwan. J. Mar. Sci. Technol. 2012, 20, 173-186. [CrossRef]

68. Oswald Beiler Michelle, R.; Treat, C. Integrating GIS and AHP to Prioritize Transportation Infrastructure Using Sustainability Metrics. J. Infrastruct. Syst. 2015, 21, 04014053. [CrossRef]

69. Ju-Long, D. Control problems of grey systems. Syst. Control Lett. 1982, 1, 288-294. [CrossRef] 
70. Javanmardi, E.; Liu, S. Exploring Grey Systems Theory-Based Methods and Applications in Analyzing Socio-Economic Systems. Sustainability 2019, 11, 4192. [CrossRef]

71. Zhang, Z.; Hu, B.; Shi, K.; Su, K.; Yang, Q. Exploring the dynamic, forecast and decoupling effect of land natural capital utilization in the hinterland of the Three Gorges Reservoir area, China. Sci. Total Environ. 2020, 718, 134832. [CrossRef]

72. Liang, Y.; Zheng, X.; Song, Q.; Bai, S. Analysis on the evolution of traffic network accessibility in Chinese Mainland. Geogr. Res. 2017, 36, 2321-2331.

73. Hillier, B.; Iida, S. Network and Psychological Effects in Urban Movement. In Spatial Information Theory; Springer: Berlin/Heidelberg, Germany, 2005; pp. 475-490.

74. Turner, A.; Penn, A.; Hillier, B. An Algorithmic Definition of the Axial Map. Environ. Plan. B Plan. Des. 2005, 32, 425-444. [CrossRef]

75. Zhang, X.; Ren, A.; Chen, L.; Zheng, X. Measurement and Spatial Difference Analysis on the Accessibility of Road Networks in Major Cities of China. Sustainability 2019, 11, 4209. [CrossRef]

76. Kim, H.-K.; Sohn, D.W. An analysis of the relationship between land use density of office buildings and urban street configuration: Case studies of two areas in Seoul by space syntax analysis. Cities 2002, 19, 409-418. [CrossRef]

77. Dettlaff, W. Space syntax analysis-methodology of understanding the space. PhD Interdiscip. J. 2014, 1, $283-291$.

78. Wang, L.; Chen, L. The impact of new transportation modes on population distribution in Jing-Jin-Ji region of China. Sci. Data 2018, 5, 170204. [CrossRef]

79. Kenderdine, T. China's Industrial Policy, Strategic Emerging Industries and Space Law. Asia Pac. Policy Stud. 2017, 4, 325-342. [CrossRef]

80. Li, C.; Gao, X.; Wu, J.; Wu, K. Demand prediction and regulation zoning of urban-industrial land: Evidence from Beijing-TianjinHebei Urban Agglomeration, China. Environ. Monit. Assess. 2019, 191, 412. [CrossRef] [PubMed]

81. Tian, L.; Ma, W. Government intervention in city development of China: A tool of land supply. Land Use Policy 2009, 26, 599-609. [CrossRef]

82. Rao, Y.; Zhang, J.; Xu, Q.; Wang, S. Sustainability assessment of road networks: A new perspective based on service ability and landscape connectivity. Sustain. Cities Soc. 2018, 40, 471-483. [CrossRef]

83. Asher, S.; Garg, T.; Novosad, P. The Ecological Impact of Transportation Infrastructure. Econ. J. 2020, 130, 1173-1199. [CrossRef]

84. He, P.; Gao, J.; Zhang, W.; Rao, S.; Zou, C.; Du, J.; Liu, W. China integrating conservation areas into red lines for stricter and unified management. Land Use Policy 2018, 71, 245-248. [CrossRef] 